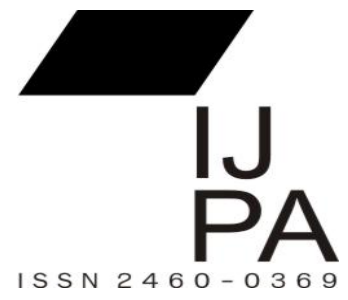

\title{
TATA KELOLA KOLABORATIF DALAM PENANGGULANGAN KEMISKINAN DI KABUPATEN PINRANG
}

\section{ABDUL RASYID SAHAR ROV VALIANT SALOMO}

\author{
Fakultas Ilmu Administrasi \\ sahar_abdulrasyid@yahoo.co.id
}

\begin{abstract}
In SDGs regime, collaborative partnership used to reduce poverty. The rise of collaborative governance discourse is just because an involvement of the multiple stakeholders in multiple organizations across multiple jurisdictions who has it's own understanding of the problem and solution differently. In this paper, we examine the implementation of collaborative governance and it's affected factors in Pinrang's poverty alleviation. Since 2016, local government initiated The Poverty Reduction Department (Bagian Penanggulangan Kemiskinan) as a special board for eradicating poverty by an integrative framework for collaborative governance. This board intended to assist on the Regional Poverty Alleviation Coordination Team (TKPKD), to integrate a number of poverty alleviation program, and also to merge the database differences between The Central Statistics Agency (BPS) and TKPKD. However, while BPK has an important role to play, there are many conditions and settings that bother for driving progressively cyclical or iterative interactions between multiple stakeholders. In addition, the Pinrang poverty rate was increased in 2016 period. BPS announced that the number of people living below the poverty line was 256.054 in 2017 or 8,5 percent of the total population. This study argues that a lack of leadership and capacity buildings shape the prospects for and challenges of initiating and sustaining collaborative governance in Pinrang's poverty alleviation program.
\end{abstract}

Keywords: Collaborative Governance, Poverty Allevation Program, Local Government 
Abstrak, Dalam rezim SDG's, pendekatan untuk mengentaskan kemiskinan adalah collaborative partnership. Diskursus ini mengemuka karena kemiskinan merupakan isu multisektoral yang dinamis dan kompleks. Pemetaan solusinya pun merujuk pada pelibatan berbagai jenjang organisasi, multidispilin, dan lintas yurisdiksi. Penelitian ini akan meninjau penerapan dan faktor yang berpengaruh pada tata kelola kolaboratif dalam penanggulangan kemiskinan di Kabupaten Pinrang dengan menggunakan metode deskriptif analitis. Pada 2016, sebagai momentum reformasi birokrasi, Pemerintah Pinrang membentuk OPD yang khusus concern dalam menanggulangi kemiskinan melalui kerangka kolaboratif antar jenjang pemerintahan dan pihak non pemerintah untuk mangakomodasi peran TKPKD Pinrang yang tidak optimal, program kemiskinan yang tidak terintegrasi, dan perbedaan Basis Data Kemiskinan (BPS-TNP2K) yang menjadi rujukan pemerintah daerah. Namun demikian, meskipun penerapan tata kelola kolaboratif diarus utamakan dalam penanggulangan kemiskinan, tetapi belum sepenuhnya menjadi solusi alternatif terhadap tingkat kemiskinan daerah yang masih konsisten di angka 8,5\%. Sampai pada tahun 2017, realisasi target angka kemiskinan Pinrang belum terwujud di angka 6\%. Penelitian ini menemukan bahwa tidak optimalnya pembangunan dimensi trust dan mutual understanding sebagai salah satu komponen esensial, juga, kapasitas pemimpin kolaborasi menjadi variabel penentu menghambat proses kolaborasi ke tingkat yang lebih iteratif dan dinamis (collaborative dynamics).

Kata kunci: Collaborative Governance, Penanggulangan Kemiskinan, Pemerintahan Lokal 


\section{PENDAHULUAN}

Pada rezim Sustainable Develeopement Goals (SDGs), kemiskinan tetap menjadi salah satu isu utama dari 17 Tujuan Pembangunan Global (TPG) sekaligus menjadi komitmen bersama dari 193 Negara anggota Perserikatan Bangsa-Bangsa (PBB), masyarakat sipil, akademisi, pihak swasta, dan masyarakat filantropi. Trend global ini membuktikan bahwa persoalan kemiskinan merupakan tantangan bangsa-bangsa di pelbagai belahan dunia yang semestinya ditanggulangi bersama secara komprehensif, integratif, dan inklusif. Premis ini sejalan dengan dokumen yang telah disepakati dalam Konferensi Tingkat Tinggi negara anggota PBB yaitu Transforming Our World: The 2030 Agenda for Sustainable, bahwa solusi alternatif dalam memberantas kemiskinan adalah terdapatnya keterlibatan semua negara dan pemangku kepentingan (stakeholders) dalam sebuah kemitraan kolaboratif (United Nations, 2015).

Secara spesifik, Rittel dan Webber (1975) menjelaskan bahwa kemiskinan merupakan salah satu dari masalah sosial dan kultural atau wicked problem yang sulit ditanggulangi karena beberapa alasan seperti beragamnya informasi atau pengetahuan yang tidak lengkap dan kontradiktif, alokasi ekonomi atau anggaran yang besar, serta dimensinya yang memiliki muatan saling berhubungan dan keterkaitan dengan yang lain. Sebagai contoh, kemiskinan merupakan masalah multidimensional karena dinilai memiliki keterkaitan dengan pendidikan, gizi, kesehatan, serta keterampilan kerja. Oleh karenanya, dibutuhkan mitigasi penanggulangan kemiskinan melalui proses dan desain tata kelola yang integratif, kolektif, dan kolaboratif.

Kabupaten Pinrang merupakan salah satu daerah yang menggunakan pendekatan kolaborasi untuk mempercapat laju pembangunan daerahnya, khusunya pada penata kelolaan pengentasan kemiskinan. Dari tinjaun lapangan, peneliti menemukan tiga tantangan dan kendala yang yang menyebabkan lambannya penanggulangan kemiskinan di Kabupaten Pinrang. Pertama, kinerja TKPKD yang dibentuk pada Tahun 2010 untuk mendorong proses perencanaan dan penganggaran agar mampu menghasilkan perumusan anggaran yang efektif serta melakukan koordinasi dan pemantauan program penanggulangan kemiskinan tahunan di daerah belum maksimal. Indikasinya, masih adanya kecenderungan ego sektoral baik dalam perencanaan maupun pelaksanaan program penanggulangan kemiskinan daerah. Selain itu, kontekstualisasi program dan indikator penerima manfaat disusun berdasarkan persepsi dan indikator masing-masing Satuan Kerja Perangkat Daerah (SKPD). Kedua, program penanggulangan kemiskinan tidak terintegrasi. Selama ini, penerima manfaat dihadapkan pada akses program penanggulangan kemiskinan yang panjang dan tentunya membutuhkan biaya transportasi yang tidak sedikit. Terakhir, adanya kendala di tingkat penerima manfaat program yaitu perbedaan data dan rendahnya tingkat validitas basis data terkait jumlah penduduk miskin dan Rumah Tangga Miskin (RTM) yang kemudian menjadi acuan angka kemiskinan daerah.

Ketiga permasalahan diatas memiliki hubungan kausal terhadap fluktuasi persentase kemiskinan di Kabuapaten Pinrang. Berdasarkan data BPS, persentase angka kemiskinan di Kabupaten Pinrang meningkat di tiap tahunnya. Tercatat, angka kemiskinan pada Tahun 2017-2018 sebesar 8,5\%. Oleh karenanya, pada 2016, pemerintah membentuk Bagian Penanggulangan Kemiskinan (B-PK) berdasarkan Perbub No. 37 Tahun 2016. Inisiatif pembentukan institusi ini adalah sebagai wujud inovasi serta komitmen reformasi birokrasi oleh pemerintah daerah. Merujuk pada uraian diatas, 
penelitian ini bertujuan untuk mengelaborasi bagaiamana proses penerapan tata kelola kolaboratif dan meninjau hal apa yang berpengaruh dalam tata kelola penanggulangan kemiskinan di Kabupaten Pinrang.

\section{TINJAUAN PUSTAKA}

Dalam memahami tata kelola kolaboratif, peneliti berangkat dari pemahaman yang utuh tentang definisi collaborative governance yang dikembangkan Emerson dan Nabatchi (2015). Secara umum, studi dan praktik tentang tata kelola kolaboratif telah dibahas oleh pelbagai akademisi dan praktisi dari berbagai disiplin ilmu dan bidang profesional. Dalam perkembangannya, kajian tata kelola kolaboratif tidak hanya menjadi tujuan penelitian dalam konteks administrasi publik, tetapi mencakup semua cabang dan disiplin ilmu. Oleh karenanya, perlu membahas beberapa perspektif dan pendekatan kunci untuk pemahaman yang lebih komprehensif pada kajian tata kelola kolaboratif. Adapun beberapa pendekatannya sebagai berikut. Pertama, Collaborative Governance as Institutional Arrangements. Pada perspektif kelembagaan, proses kolaborasi yang dilakukan para aktor harus memiliki ketentuan, ketetapan, dan pemantauan terhadap aturan yang telah disepakati bersama, mengembangkan norma-norma informal, membangun kesepahaman dan kepercayaan bersama, serta merumuskan strategi dan konsep dalam pelaksanaannya.

Kedua, Collaborative Governance as Structural Relations. Pada pendekatan ini, kolaborasi ditekankan pada pola interaksi dan konektivitas. Proses kolaborasi dilihat sebagai proses interdependensi antar aktor dan organisasi baik secara formal maupun informal. Gagasan yang mendasari yaitu kecenderungan individu yang terpengaruh dalam pola interaksi sosial yang berulang dalam konektivitas dan jejaring sosial tersebut. Selain itu, partisipasi dalam jejaring interpersonal akan mempengaruhi para aktor dalam membangun modal sosial dan pengaruh (kekuasaan) dalam masyarakat.

Ketiga, Collaborative Governance as an Advocacy Coalition. Pada awalnya, kerangka advocacy coalition ini berawal dari hipotesis yang disusun Sabatier dan Smith (1993) yang menjelaskan bahwa dalam implementasi kebijakan, terdapat sub sistem yang saling berlawanan. Oleh karenanya, advocacy coalition ini dibutuhkan dalam mempengaruhi sub sistem yang memiliki kesamaan untuk berkoordinasi dalam pelbagai jenjang lembaga publik maupun swasta. Dalam konteks tata kelola kolaboratif, perspektif ini juga diperlukan mengingat muatan prinsip pelibatan pelbagai aktor yang bertujuan menghasilkan konsensus sebagai sebuah keniscayaan dalam kolaborasi.

Terakhir, dalam memahami pengembangan dan pengujian akademik maupun praksis terkait tata kelola kolaboratif, Emerson dan Nabatci (2015) merumuskan kerangka integratif tata kelola kolaboratif dalam tiga dimensi bertingkat yaitu system contex, drivers, dan collaborative dynamics. Meskipun kerangka integratif menyuguhkan dimensi dan komponen tata kelola kolaboratif tetapi tidak secara simultan kerangka ini mampu cocok dan aplikatif terhadap semua kasus dan isu yang ada ( $a$ one size fit for all). Kerangka integratif ini dimaksudkan untuk membantu dalam mengidentifikasi perilaku, kausalitas, serta struktur elemen dalam proses kolaborasi. Pada prinsipnya, meskipun ada pelbagai kajian dan kerangka teori yang dikembangkan para scholars dan praktisi terkait tata kelola kolaboratif, tetapi Emerson dan Nabatchi (2015) menawarkan kerangka yang relatif komprehensif. Mereka menambahkan, dalam kerangka yang dibangun, ada aspek- 
aspek kunci yang mempengaruhi dinamika tata kelola kolaboratif yang luput dianalisa oleh akademisi lain seperti Ansel dan Gash (2012).

\section{METODE PENELITIAN}

Disain penelitian ini adalah metode deskriptif analisis yaitu menggambarkan penerapan tata kelola kolaboratif dan meninjau hal berpengaruh dalam penanggulangan kemiskinan di Kabupaten Pinrang. Adapun sumber data yang menjadi objek kajian adalah hasil wawancara informan kunci di Kabupaten Pinrang serta telaah dokumen resmi Pemerintah Daerah Kabupaten Pinrang serta dokumentasi dari berbagai media online dan offline. Teknik pengumpulan data berupa wawancara mendalam dan telaah dokumentasi kemudian dianalisis menjadi temuan penelitian. Terkait pengujian keabsahan data, peneliti menggunakan teknik triangulasi sumber baik yang berasal dari wawancara informan kunci, maupun tinjauan dokumentasi.

\section{PEMBAHASAN}

\section{A. Model Tata Kelola Kolaboratif Dalam Penanggulangan Kemiskinan Kabupaten Pinrang}

Dalam konteks pemerintahan lokal, fenomena terkait pelbagai tantangan dan kelemahan kebijakan dalam penanggulangan kemiskinan di Kabupaten Pinrang yang bersifat ego sentris berimplikasi terhadap fluktuasi angka kemiskinan daerah sebagaimana tren peningkatan pada tiga tahun terakhir. (lihat Tabel 1).

Tabel 1.1 Tren Peningkatan Angka Kemiskinan Kabupaten Pinrang

\begin{tabular}{|c|c|c|c|}
\hline $\begin{array}{c}\text { INDIKATOR } \\
\text { KEMISKINAN }\end{array}$ & 2014 & 2015 & 2016 \\
\hline $\begin{array}{c}\text { Jumlah Rumah } \\
\text { Tangga Miskin (RTM) }\end{array}$ & 29.900 & 30.500 & 31.280 \\
\hline $\begin{array}{c}\text { Persentase } \\
\text { Penduduk Miskin (\%) }\end{array}$ & $8,20 \%$ & $8,34 \%$ & $8,48 \%$ \\
\hline $\begin{array}{c}\text { Indeks } \\
\text { Kedalaman Miskin }\end{array}$ & 1 & 1,66 & 0,36 \\
\hline $\begin{array}{c}\text { Indeks } \\
\text { Keparahan Miskin }\end{array}$ & 228,150 & 234,897 & 250,163 \\
\hline $\begin{array}{c}\text { Garis } \\
\text { Kemiskinan } \\
\text { (RP/Kap/Bulan) }\end{array}$ & & 0,52 & \\
\hline
\end{tabular}

Sumber: BPS, diolah peneliti

Menurut data yang dirilis BPS, jumlah RTM pada 2016 meningkat di angka 31.280 jiwa dari 29.900 jiwa pada tahun 2014. Selain itu, persentase penduduk miskin juga secara simultan meningkat dari $8,20 \%$ pada 2014 menjadi $8,84 \%$ pada 2016 . Artinya, 
terdapat permasalahan tata kelola pengentasan kemiskinan di daerah yang tidak efektif dan signifikan.

Dari proses wawancara awal dengan A. Irna Amilia selaku Kasubag tata laksana, kinerja dan pelayanan publik pada Bagian Organisasi dan Tata Laksana Sekertariat Daerah Kabupaten Pinrang, peneliti menemukan bahwa terdapat tiga penyebab lambannya penanggulangan kemiskinan daerah di Kabupaten Pinrang. Pertama, pembentukan Tim Koordinasi Penanggulangan Kemiskinan Daerah (TKPKD) Kabupaten Pinrang yang diharapkan mampu mendorong proses perencanaan dan penganggaran agar mampu menghasilkan perumusan anggaran yang efektif serta melakukan koordinasi dan pemantauan program penanggulangan kemiskinan tahunan di daerah belum maksimal.

Secara spesifik, pada tingkat pelaksana program, terdapat kecenderungan ego sektoral baik dalam perencanaan maupun pelaksanaan program penanggulangan kemiskinan daerah. Terdapatnya kontekstualisasi program dan indikator penerima manfaat disusun berdasarkan persepsi dan indikator masing-masing Satuan Kerja Perangkat Daerah (SKPD). Temuan ini mengindikasikan rendahnya tingkat keterpaduan program penanggulangan kemiskinan di Kabupaten Pinrang. Oleh karenanya, kondisi ini akan berdampak pada pelaksanaan program penanggulan kemiskinan dimana hasil yang diperoleh tidak memberikan perubahan yang signifikan bagi peningkatan taraf hidup penerima manfaat, karena masing-masing program SKPD menyasar penerima manfaat yang berbeda.

Kedua, program penanggulangan kemiskinan tidak terintegrasi. Selama ini, penerima manfaat dihadapkan pada akses program penanggulangan kemiskinan daerah yang panjang dan tentunya membutuhkan biaya transportasi yang tidak sedikit. Warga miskin yang ingin mengakses program harus melalui beberapa SKPD sebelum dapat merasakan manfaat program penanggulangan kemiskinan. (lihat Gambar 1.1).

\section{Gambar 1.1. Model Penanggulangan Kemiskinan Kabupaten Pinrang}

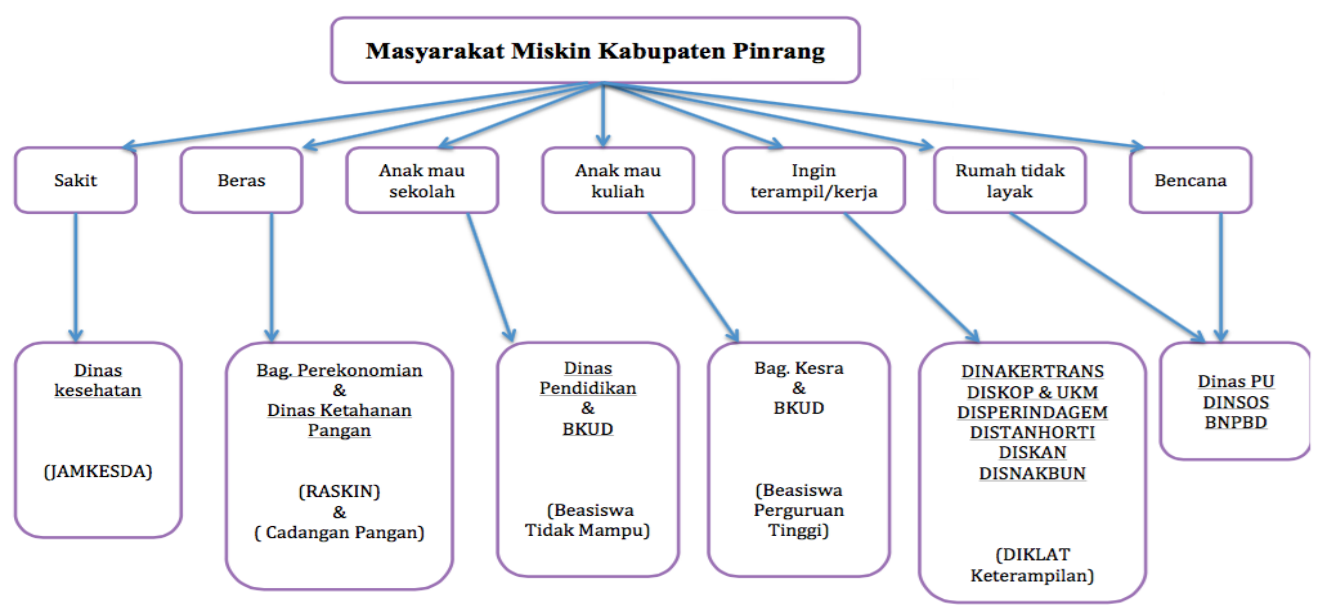

Sumber: Draft Paparan Focus Group Discussion Penanggulangan Kemiskinan Pemerintah Kabupaten Pinrang 2017. 
Gambar diatas mengilustrasikan tata kelola penanggulangan kemiskinan yang tidak efektif dan efisien. Sebagai contoh, satu Rumah Tangga Miskin harus mendatangi Dinas Kesehatan untuk jaminan kesehatan seluruh anggota keluarganya, Dinas Pendidikan dan Kebudayaan untuk pendidikan anak, dinas sosial untuk mengakses bantuan usaha bagi keluarga tidak mampu dan atau Bagian Perekonomian Sekertariat Daerah untuk mengakses bantuan beras miskin (Raskin). Proses yang mereka lakukan ini secara simultan tidak menjamin bahwa mereka langsung menjadi salah satu penerima manfaat. Di sisi lain, dengan kondisi terkait ketidaktahuan prosedur dan keterbatasan informasi, serta perbedaan basis data dan kriteria penerima manfaat program menyebabkan masyarakat miskin terkendala dalam menindaklanjuti ketentuan yang diberlakukan oleh masing-masing SKPD

Ketiga, adanya kendala di tingkat penerima manfaat program. Kendala yang ditemukan yaitu terdapatnya perbedaan data dan/atau rendahnya tingkat validitas basis data terkait jumlah penduduk miskin dan Rumah Tangga Miskin (RTM) yang kemudian menjadi acuan angka kemiskinan daerah (lihat Gambar 1.2).

\section{Gambar 1.2. Perbedaan Basis Data Masyarakat Miskin Tahun 2016}
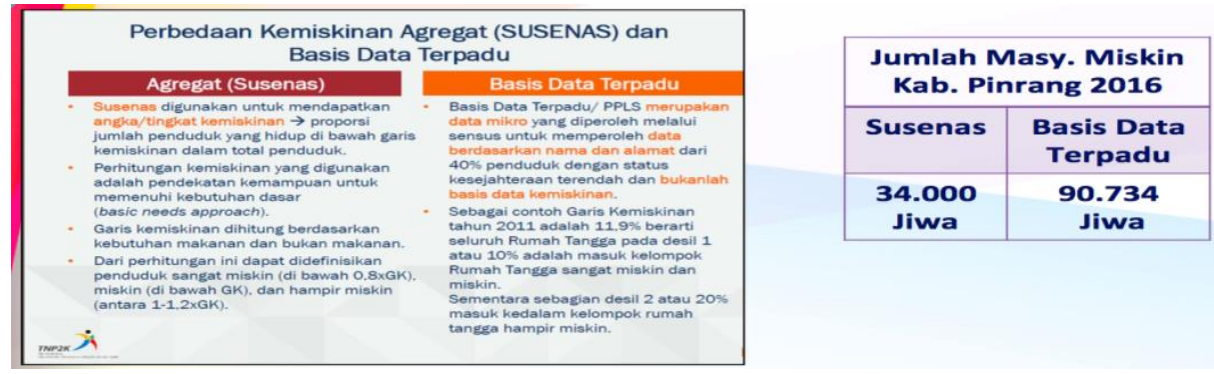

Sumber: Draft FGD Penanggulangan Kemiskinan Kabupaten Pinrang 2017.

Jika dicermati, terdapat perbedaan basis data tahunan terkait jumlah masyarakat miskin yang disusun oleh BPS dalam hal ini Agregat Survey Sosial Ekonomi Nasional (SUSENAS) dengan hasil pemutakhiran basis data terpadu TP2NK di Kabupaten Pinrang. Selanjutnya, ditemukannya fakta lapangan bahwa masih ada penduduk miskin dan atau RTM yang belum terdata dalam SUSENAS maupun basis data terpadu yang dimiliki TP2NK. Fakta tersebut seringkali memicu persoalan antar warga selaku penerima manfaat yang kemudian menjadi tantangan bagi pemerintah setempat selaku pelaksana program dalam melaksanakan percepatan penaggulangan kemiskinan yang adil dan berkelanjutan.

Dalam konteks tata kelola penanggulangan kemiskinan di Kabupaten Pinrang, Bupati selaku pejabat publik dan pimpinan administratif tertinggi di daerah, membentuk Bagian Penanggulangan Kemiskinan di Sekretariat Daerah sekaligus wujud dari komitmen kepada pemerintah pusat terkait PP No. 18 Tahun 2016 tentang perangkat daerah yang bertujuan untuk mengarahkan pembentukan perangkat daerah yang rasional, proporsional, efektif, dan efisien. Bagian Penanggulangan Kemiskinan (B-PK) ini dibentuk berdasarkan Peraturan Daerah Nomor 6 Tahun 2016 tentang Pembentukan dan Susunan Perangkat Daerah yang dijabarkan dalam Peraturan Bupati Pinrang Nomor 37 Tahun 2016. Tujuannya untuk mengintegrasikan program penanggulangan kemiskinan yang selama ini dijalankan secara ego sektoral masing-masing SKPD dan juga merangkul 
pihak-pihak non pemerintah yang ingin terlibat dan memiiki kepentingan yang sama dalam mengentaskan kemiskinan di Kabupaten Pinrang. Juga, mendukung kerja TKPKD, serta menyiapkan data tunggal yang akan dijadikan rujukan penanggulangan kemiskinan daerah, termasuk memfasilitasi masyarakat miskin yang tidak terdata dalam data TNP2K yang menjadi rujukan nasional.

Pasca pembentukan Bagian Penanggulangan Kemiskinan, model dan alur tata kelola dalam penanggulangan kemiskinan di Kabupaten Pinrang cenderung lebih integratif, koordinatif, dan kolaboratif. Indikasinya, dapat ditelusuri melalui proses dan alur pemberian bantuan yang sifatnya pemberdayaan dan bantuan langsung dalam kucuran dana sosial kepada masyarakat. Sebagai missal, bagi anggota masyarakat yang ingin mengakses dan menerima manfaat program tidak lagi harus melewati berbagai jenjang birokrasi, mereka cukup mendatangi kantor bagian penanggulangan kemiskinan yang nantinya diakomodir secara responsif. Adapaun alur teknisnya, pertama, bagian penanggulangan kemiskinan menerima pengaduan data yang nantinya akan divalidasi pada basis utama yang telah dipadukan oleh BPS dan TNP2K. Kedua, setelah proses validasi dilakukan, Bagian Penanggulangan Kemiskinan menugaskan Tim Verifikasi Kabupaten yang melibatkan pihak SKPD berdasarkan basis kemiskinan yang akan dituju. Terakhir, setelah verifikasi dilakukan, pihak SKPD terkait akan melaksanakan tugas dan fungsinya masing-masing sesuai bidang dan basis kemiskinan yang telah dikategorikan.

Dalam perkembangannya, proses perumusan kebijakan, pengambilan keputusan dan manajemen penanggulangan kemiskinan di Kabupaten Pinrang tidak hanya melibatkan level atau tingkatan pemerintahan (SKPD) saja, tetapi pelibatan unsur non pemerintah juga diakomodir. Hal ini dikarenakan proses kolaborasi interorganisasi yang telah dilakukan selama ini dirasa belum maksimal, mengingat keterbatasan anggaran yang dimiliki pemerintah daerah. Tercatat, ada beberapa unsur non pemerintah yang turut berpartisipasi dalam kegiatan penanggulangan kemiskinan. Untuk lebih jelasnya lihat gambar 1.3 dibawah ini.

\section{Gambar 1.3. Model Kolaborasi Penanggulangan Kemiskinan Kab. Pinrang}

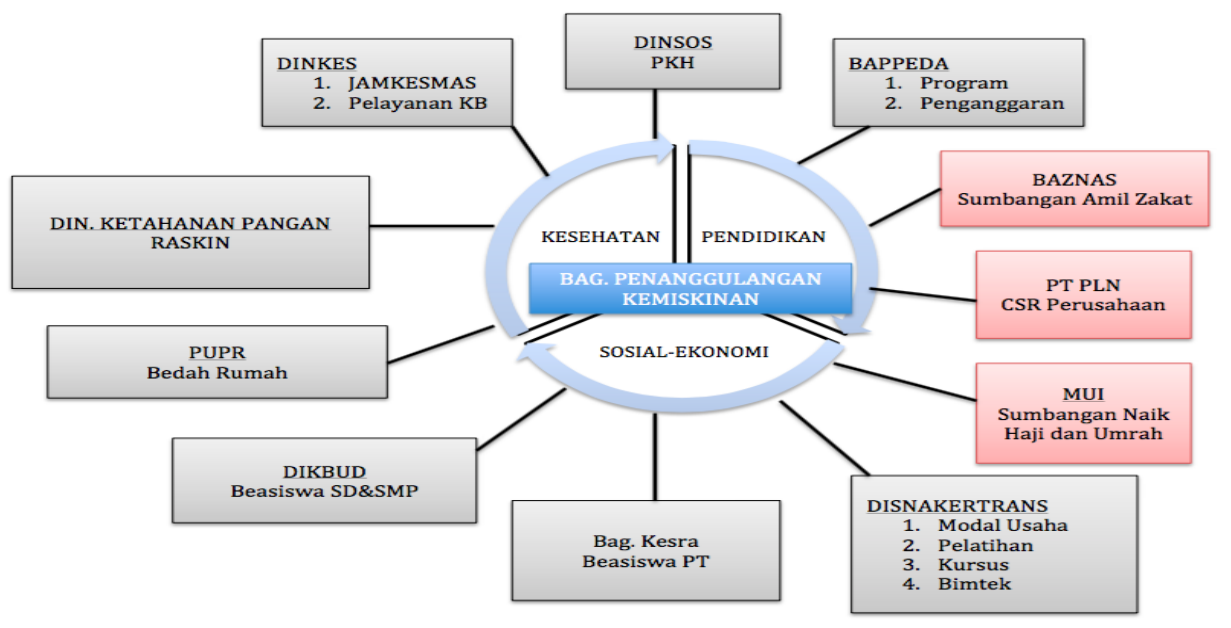

Sumber: Draft Paparan FGD Penanggulangan Kemiskinan Kab. Pinrang 2017 
Gambar diatas mengilustrasikan bahwa tata kelola penanggulangan kemiskinan kabupaten Pinrang mampu membentuk model kolaboratif dengan pelbagai stakeholders melalui instrumen penyatuan program dengan pelbagai pihak yang dibentuk dari pertemuan dan diskusi secara rutin dari masing-masing stakeholders. Menurut Emerson dan Nabatchi (2015), dalam proses awal kolaborasi, jika potensi konflik rendah maka akan mempermudah aktor dan anggota kolaborasi menimbulkan kesepahaman dan kesepakatan bersama.

Berdasarkan konteks kolaborasi diatas, terdapat pihak non pemerintah didalamnya yang direpresentasikan oleh MUI, BAZNAS, dan Yayasan Baitul Maal (YBM) PT PLN. Para pihak tersebut turut serta memberikan bantuan teknis berupa sumbangan amil zakat kepada masyarakat yang telah dikategorikan miskin, bantuan pemberdayaan masyarakat serta menyalurkan bantuan kelistrikan dan non kelistrikan oleh YBM PT PLN kepada masyarakat Pinrang.

Sebagai bentuk komitmen dalam mengintegrasikan program dan pelbagai kepentingan bersama, pihak pihak terkait (sebagaimana gambar 1.3) melakukan pertemuan formal dan informal secara rutin dan berulang untuk melakukan diskusi dan diseminasi terkait aturan main kolaborasi dan kerja kolektif dalam penanggulangan kemiskinan. Pertemuan formal tersebut kemudian ditindak lanjuti dalam penandatanganan Memorandum of Understanding MoU tentang program dan kegiatan bersama pada tanggal 5 Agustus 2018. Menurut Emerson dan Nabatchi (2015), dalam collaborative dynamics, adanya dorongan dan tuntutan publik maka memungkinkan pihak pemerintah dan non pemerintah melaksanakan pertemuan baik secara tatap muka vis a vis maupun secara virtual untuk mengakomodir tuntutan tersebut. Selain itu, pada peroses awal kolaborasi, pelibatan unsur non pemerintah dalam penanggulangan kemiskinan di kabupaten Pinrang dapat berjalan dengan mudah disebabkan adanya sense of purpose yang selaras dalam memandang isu kemiskinan.

\section{B. Hal yang Berpengaruh dalam Proses Tata Kelola Kolaboratif dalam Penanggulangan Kemiskinan di Kabupaten Pinrang}

Menurut Emerson dan nabatchi (2015) bahwa ada enam aspek yang memiliki relevansi dan berpengaruh dalam proses tata kelola kolaboratif, diantaranya policy and legal framework, socioeconomic and cultural characteristics, network characteristic, political dynamics and power relations, history of conflict, serta, public services or resources conditions. Keenam aspek tersebut merupakan satu kesatuan yang dikategorikan dalam dimensi system context. Selain itu, uncertainty, interdependence, consequential incentives, dan initiating leadership juga merupakan aspek yang fundamental untuk mendorong pihak lintas sektor melakukan kolaborasi. Dibawah ini, akan dijelaskan dan ditelusuri hala apa saja yang berpengaruh pada proses tata kelola kolaboratif dalam penanggulangan kemiskinan di Kabupaten Pinrang. Tentunya dengan merujuk beberapa dari aspek system context dan drivers yang telah dirinci diatas. 


\section{The System Context | Konteks Sistem dalam Tata Kelola Penanggulangan Kemiskinan di Kabupaten Pinrang.}

Upaya kolaborasi yang di inisiasi oleh pemerintah daerah dalam menata kelola penanggulangan kemiskinan tidak berjalan dengan sendirinya. Artinya, pemerintah bukan faktor tunggal mengapa tata kelola kolaboratif di arus utamakan untuk mengentaskan kemiskinan. Peneliti telah mengidentifikasi bahwa terdapat konteks sistem yang mempengaruhi pemerintah untuk segera menetapkan pendekatan koordinatif, kolaboratif, serta nilai "keroyokan" dalam program dan kegiatan penanggulangan kemiskinan. Ada enam aspek utama yang saling berinteraksi dan beririsan dan secara signifikan berpengaruh dalam membentuk rezim kolaboratif, diantaranya public services or resources conditions, policy and legal framework, socioeconomic and cultural characteristics, network characteristics, political dynamics and power relations, history of conflict.

Pertama, yaitu public services or resources conditions yang dimaknai peneliti sebagai kondisi objektif tata kelola penanggulangan kemiskinan yang didalamnya termasuk bentuk pelayanan publik yang dikemas pemerintah Kabupaten Pinrang selama ini. Artinya, kondisi dan performa layanan publik terkait mekanisme yang diatur pemerintah daerah dalam menerima pengaduan masyarakat untuk memperoleh manfaat program pengentasan kemiskinan. Dalam dokumen dan draft yang ditelaah di pengarsipan kantor PINDU, ditemukan bahwa selama ini, masyarakat miskin selaku penerima manfaat dihadapkan pada alur program penanggulangan kemiskinan daerah yang panjang dan tentunya membutuhkan biaya transportasi yang tidak sedikit. Warga miskin yang ingin mengakses program harus melalui beberapa SKPD sebelum dapat merasakan manfaat program penanggulangan kemiskinan. Kondisi objektif lainnya terkait kinerja TKPD yang belum optimal dalam mengintegrasikan program yang tersebar di SKPD. Juga, adanya kendala di tingkat penerima manfaat program. Kendala yang ditemukan yaitu terdapatnya perbedaan data dan/atau rendahnya tingkat validitas basis data terkait jumlah penduduk miskin dan Rumah Tangga Miskin (RTM) yang kemudian menjadi acuan angka kemiskinan daerah. Hal inilah yang menurut kanalisis peneliti, menyebabkan peningkatan angka kemiskinan daerah berdasarkan data yang dikeluarkan BPS pada 2014-2016 terus meningkat.

Kedua, pada aspek policy and legal framework, kerangka kebijakan dan hukum yang muncul dari sistem legislatif, regulasi administratif dan yudisial akan mempengaruhi ruang lingkup dalam pengambilan keputusan publik serta aksi kolaborasi. Dalam system context yang ada pada tata kelola kolaboratif dalam penanggulangan kemiskinan di Kabupaten Pinrang, adanya target pemerintah dalam Rencana Pembangunan Jangka Menengah Nasional 2015-2019 dimana isu kemiskinan merupakan salah satu tujuan pembangunan nasional yang harus segera dituntaskan. Juga, adanya komitmen tentang Pelaksanaan Pencapaian 
Tujuan Pembangunan Berkelanjutan yang diwadahi pemerintah dalam Peraturan Presiden (Perpres) No.59 Tahun 2017. Selain itu, adanya PP No. 18 Tahun 2016 tentang perangkat daerah yang bertujuan untuk mengarahkan pembentukan perangkat daerah yang rasional, proporsional, efektif, dan efisien. Serta, Peraturan Daerah Nomor 6 Tahun 2016 tentang Pembentukan dan Susunan Perangkat Daerah. Berangkat dari muatan kebijakan dan kerangka hukum tersebut, maka dinilai memiliki pengaruh terhadap inisiasi kerjasama dan kolaborasi lintas sektoral dan yurisdiksi di wilayah Kabupaten Pinrang.

Ketiga, karakteristik sosial ekonomi dan budaya juga mempengaruhi kualitas dan kondisi layanan publik. Selain itu, hal tersebut juga akan merefleksikan bagaimana besaran sumber daya yang akan digunakan dalam kerjakerja kolaboratif dan kolektif bagi para stakeholders. Berdasarkan kajian yang dilakukan BPS di Kabupaten Pinrang, wilayah ini merupakan distrik administratif yang menunjukkan pertumbuhan penduduk dan ekonomi yang relatif baik di Propinsi Sulawesi Selatan. Adapun untuk tingkat Angka Harapan Hidup (AHH) pada tahun 2012-2017, Kabupaten Pinrang menunjukkan tren positif setiap tahunnya. Tercatat, pada Tahun 2017, AHH Kabupaten Pinrang berada pada angka 68,55. Artinya, lama hidup masyarakat di Kabupaten Pinrang relatif tinggi. Lebih lanjut, tingkat daya beli masyarakat juga cukup tinggi. Juga, untuk laporan pada Tahun 2017 tentang Paritas Daya Beli masyarakat Pinrang yang menunjukkan tren positif yaitu di angka 10.281 ribu rupiah. Angka ini lebih tinggi jika dibandingkan paritas daya beli pada level Provinsi. Menjadi penting diketahui, bahwa secara umum etnis masyarakat Pinrang memang memiliki budaya konsumtif yang tinggi. Selain itu, letak geografis daerah ini cukup strategis dikarenakan tata letak daerah yang berdekatan dengan kota Makassar dan Pare-Pare yang merupakan distrik penyangga Provinsi Sulawesi Selatan. Oleh karenanya, secara aksesibilitas dapat mempermudah pembangunan dan pertumbuhan ekonomi masyarakat.

Keempat, untuk aspek network characteristics sendiri mengacu pada rekam jejak antara struktur kelembagaan yang saling beririsan serta memiiki interdependensi antar organisasi. Pada konteks tata kelola kolaboratif dalam penanggulangan kemiskinan di Kabupaten Pinrang, pola relasi antara masingmasing kelembagaan memiliki hubungan yang kuat khususnya pada level institusi antar jenjang pemerintahan dan non pemerintahan sehingga aspek ini dapat menunjung inisiasi kerja kolektif dan kolaboratif. Secara spesifik, karakter jejaring organisasi publik di Pinrang memiliki pola interdependensi, terlebih, BPK merupakan organisasi perangkat dari Sekertariat Daerah Kabupaten Pinrang sehingga inisiatif untuk bekerjasama secara kolektif terhadap pemangku lintas sektor cenderung tidak memiliki pengaruh dan hambatan yang signifikan.

Kelima, yaitu aspek yang tidak kalah berpengaruh pada proses tata kelola kolaboratif dalam penanggulangan kemiskinan di Kabupaten Pinrang adalah dinamika politik dan relasi kekuasaan. Aspek ini menurut Emerson dan Nabatchi 
(2015) paling potensial dan fundamental mempengaruhi perjalanan kolaborasi itu sendiri. Dinamika politik di Kabupaten Pinrang relatif stabil tanpa pergolakan massa dan organisasi akar rumput lokal, selain itu konstelasi politik juga relatif stabil. Tercatat, Bupati Pinrang saat ini sudah menduduki jabatan selama dua periode kepemimpinan sejak Tahun 2008 sampai pada Tahun 2018. Dengan modal politik semacam ini, figur ini mampu memberikan political will terhadap kerja-kerja kolaboratif di masa kepemimpinannya. Juga, relasi kekuasaan yang ada dapat ditelusuri melalui mekanisme kontrol organisasi perangkat daerah oleh pimpinan daerah yang menduduki jabatan politis dari hasil kontestasi elektoral. Relasi kekuasaan yang tebangun dalam lingkungan pemerintahan dan non pemerintahan menunjukkan soliditas ketika figur Bupati menunjukkan legal standing dan political will baik secara formal dan informal.

Terakhir, aspek esensial lainnya dalam system context adalah rekam jejak konflik dan perselisihan antar organisasi di masa lalu. Aspek ini mampu mempengaruhi bagaimana pembangunan relasi antar lembaga menuju proses kolaborasi. Pada tataran konflik antar organisasi baik dari elemen pemerintah daerah maupun organisasi non pemerintah di Kabupaten Pinrang menunjukkan stabilitas. Tren ini memiliki hubungan kausal dengan Bupati yang memiliki rentang kepemimpinan selama dua periode. Selama kepemimpinannya, tidak ditemukan dokumen dan fakta baik dari media lokal maupun nasional terkait konflik vertikal dan horizontal pada tataran OPD, non pemerintah, bahkan LSM lokal.

Berdasarkan aspek yang telah dijelaskan diatas menunjukkan bahwa keenam aspek tersebut dapat berpengaruh pada pembentukan maupun hambatan pada rezim kolaboratif. Selain itu, keenam aspek tersebut juga mampu mempengaruhi secara inkremental bahkan mengevolusi atas kelancaran maupun tantangan upaya aksi kolektif dan kolaboratif di masa yang akan datang.

\section{Drivers | Aspek Pendorong Tata Kelola Kolaboratif dalam Penanggulangan Kemiskinan di Kabupaten Pinrang}

Selain system context, ada empat komponen yang menjadi drivers dalam menginisiasi tata kelola kolaboratif, diantaranya, uncertainty, interdependence, consequential incentives, dan initiating leadership. Empat komponen ini mampu menjadi aspek berpengaruh baik dalam menginisiasi tata kelola kolaboratif maupun dalam proses kolaborasi yang sedang berlangsung. Pada tata kelola kolaboratif dalam penanggulangan kemiskinan di Kabupaten Pinrang, empat komponen ini hadir dalam rangka memprakarsai agar kolaborasi dilaksanakan maupun memotivasi manakala aksi kolaborasi menemui kebuntuan. Berikut ini akan dijelaskan secara seistematis bagaimana keempat aspek ini sebagai komponen yang berpengaruh dalam tata kelola kolaboratif di Kabupaten Pinrang. 
Pertama, dari aspek uncertainty, hasil kajian PBB yang dituangkan dalam draft "Transforming our world: the 2030 agenda for sustainable developement menunjukkan bahwa kemiskinan merupakan wicked problem yang menjadi fokus pembangunan baik pada aras internasional maupun nasional saat ini. Kondisi ketidakpastian ekonomi global dapat mempengaruhi turbulensi pembangunan suatu bangsa, khususnya pada kondisi ekonomi masyarakat yang dapat memicu kerentanan dalam memenuhi kebutuhan dasar makanan maupun non makanan. Kondisi ketidakpastian inilah yang menjadi fokus pemerintah saat ini. Dalam konteks tata kelola kolaboratif penanggulangan kemiskinan di Kabupaten Pinrang saat ini, belum ada organisasi pemerintah dan non pemerintah yang mampu menyelesaikan persoalan kemiskinan secara monosektoral. Data BPS menunjukkan bahwa persentase penduduk miskin dari 2014-2017 terus meningkat tiap tahunnya.

Kedua, dari aspek interdependence, pada level pemerintahan lokal, khususnya di Kabupaten Pinrang, pemerintah telah memetakan kebutuhan masyarakat miskin daerahnya yaitu pemenuhan sandang, pangan, papan, kesehatan, pendidikan, keterampilan, kesempatan kerja, dan infrastruktur. Dari berbagai aspek kebutuhan masyarakat miskin tersebut, maka akan menghasilkan interdependensi antar organisasi lintas sektoral. Sebagai misal, pendanaan atas program penanggulangan kemiskinan yang terbatas, kuantitas dan kapasitas sumberdaya manusia dan organisasi, serta orientasi terhadap penurunan kemiskinan daerah yang menjadi fokus masing-masing pihak sehingga mendorong Pemerintah untuk melakukan kerja kolektif.

Ketiga, consequential incentives, berangkat dari fokus permasalahan yang sama yaitu kendala tata kelola penanggulangan kemiskinan yang dihadapi masing-masing pihak terkait dimensi kemiskinan yang begitu kompleks dan multidimensional, serta tuntutan interdependensi masing-masing pihak yang akan membagi tugas dan tanggung jawab kelembagaan sesuai basis kemiskinan yang ada, maka akan mengarahkan pada consequential incentives pada masing-masing pihak khususnya pada jenjang pemerintahan berupa insentif atas tingkat kepercayaan masyarakat terhadap pemerintah daerah.

Terakhir, initiating leadership. Aspek ini merupakan faktor fundamental yang mendorong kolaborasi diprakarsai serta berperan penting menjadi trigger ketika proses kolaborasi mengalami kebuntuan. Meskipun aspek uncertainty, interdependence, dan consequential incentives mengemuka, tetapi tanpa komitmen Bupati Pinrang, maka tata kelola kolaboratif yang mewujud dalam Bagian Penanggulangan Kemiskinan Sekertariat Daerah Kabupaten Pinrang tidaka akan terbentuk. Sumbangsih Bupati Pinrang dalam memprakarsai kerja kolektif dalam pengentasan kemiskinan melalui Perbup No 18 Tahun 2018 merupakan faktor kunci pada tata kelola kolaboratif dalam penanggulangan kemiskinan di Kabupaten Pinrang. Secara spesifik, Bupati Pinrang berinisiatif dalam melemparkan diskursus terkait kerja kolektif dalam rencana pembangunan 
daerah, khususnya mengentaskan kemiskinan melalui Talk Show Halo Bumi Lasinrang secara berkala dan iteratif kepada SKPD, YBM PT PLN, MUI, Baznas, dan Kemenag Kabupaten Pinrang.

\section{PENUTUP (KESIMPULAN DAN SARAN)}

Merujuk pada analisis data yang ada tentang tata kelola kolaboratif dalam penanggulangan kemiskinan di Kabupaten Pinrang menunjukkan bahwa tata kelola kolaboratif dalam penanggulangan kemiskinan diwujudkan dalam pembentukan instansi yang diperuntukkan khusus untuk menata kelola penanggulangan kemiskinan yaitu Bagian Penanggulangan Kemiskinan Sekertariat Daerah kabupaten Pinrang. Pembentukan bagian ini merupakan inisiatif dari pemerintah daerah untuk mengkoordinir program kemiskinan yang tidak terintegrasi dan menekan angka kemiskian yang meningkat tiap tahun di Kabupaten Pinrang melalui instrumen kerja secara kolektif. Secara spesifik, dimensi collaborative dynamics pada penerapa tata kelola kolaboratif dalam penanggulangan kemiskinan di Kabupaten Pinrang telah terpenuhi namun belum optimal. Pada komponen principled engagement, adanya pertemuan formal maupun informal secara iteratif sebelum dan setelah B-PK dibentuk dapat diwujudkan oleh semua stakeholders. Juga, dalam proses deliberasi pada forum formal dan diskusi telah diarus utamakan khususnya melalui platform talkshow "Halo Bumi Lasinrang". Di sisi lain, pada komponen shared motivation belum mewujud secara inklusif. Belum optimalnya pembangunan trust dan mutual understanding menjadikan trajektori untuk berkomitmen terhadap proses kolaborasi. Hal ini disebabkan karena latar belakang kepangkatan pemimpin kolaboratif (eselon III) lebih rendah diantara stakeholders dari jenjang pemerintahan yang memiliki kepangkatan lebih tinggi (eselon II). Tren tersebut juga mempengaruhi komponen principled engagement dan capacity for joint action. Lebih lanjut, kurangnya follow up dari mekanisme procedural/institutional arrangement yang disepakati dalam skema kolaborasi antar stakeholders dan MoU disebabkan oleh permasalahan trust dan mutual understanding diatas.

Lebih lanjut, Initiating leadership merupakan faktor determinan yang mendorong kolaborasi diprakarsai serta berperan penting menjadi trigger ketika proses kolaborasi mengalami kebuntuan. Meskipun aspek uncertainty, interdependence, dan consequential incentives mengemuka, tetapi tanpa komitmen Bupati Pinrang, maka tata kelola kolaboratif yang mewujud dalam Bagian Penanggulangan Kemiskinan Sekertariat Daerah Kabupaten Pinrang tidaka akan terbentuk. Sumbangsih Bupati Pinrang dalam memprakarsai kerja kolektif untuk mengentaskan kemiskinan melalui Perbup No 18 Tahun 2018 merupakan faktor kunci pada tata kelola kolaboratif dalam penanggulangan kemiskinan di Kabupaten Pinrang. Secara spesifik, Bupati Pinrang berinisiatif 
dalam melemparkan diskursus terkait kerja kolektif dalam rencana pembangunan daerah, khususnya melalui Talk Show Halo Bumi Lasinrang secara berkala dan iteratif kepada SKPD, YBM PT PLN, MUI, Baznas, dan Kemenag Kabupaten Pinrang.

Merujuk pada kesimpulan diatas, peneliti memberikan rekomendasi sebagai diskursus dan tawaran dialektis terkait penerapan tata kelola kolaboratif baik secara akademis maupun praksis sebagai berikut. Memperkuat otonomi dan legitimasi kepada pemimpin kolaboratif yang di emban oleh Bagian Penanggulangan Kemiskinan Sekertariat Daerah Kabupaten Pinrang baik secara kepangkatan maupun secara aturan hukum yang didefiinisikan dalam peraturan daerah yang mampu mengikat semua stakeholders. Selanjutnya, memberikan pedoman secara komprehensif kepada para stakeholders terkait model ideal dan pengetahuan tata kelola kolaboratif khususnya dalam pengentasan kemiskinan di kabupaten Pinrang dengan memanfaatkan dan mendayagunakan tenaga profesional dan para pakar agar praktik tata kelola kolaboratif dapat terarah secara inklusif.

Meskipun ada pelbagai riset dan penelitian terkait studi maupun kajian tata kelola kolaboratif di Indonesia, namun tetap diharapkan para scholars dapat melanjutkan riset tentang kajian serupa pada penelitian selanjutnya. Mengingat, dimensi dan komponen tata kelola kolaboratif tidak cocok dan aplikatif terhadap semua kasus dan isu yang ada (a one size fit for all) pada lokus dan wilayah tertentu, belum lagi karakteristik daerah di Indonesia yang plural. Rekomendasi ini dimaksudkan untuk membantu khazanah kelimuan, khusunya pada ranah administrasi publik dalam mengidentifikasi perilaku, kausalitas, serta struktur elemen dalam proses kolaborasi di Indonesia

\section{DAFTAR PUSTAKA}

Emerson, Kirk, and Tina Nabatchi. 2015. Collaborative Governance Regime. Georgetown University Press: Washington, DC.

McGinnis, Michael D. 2011. "An Introduction to IAD and the Language of the Ostrom Workshop: A Simple Guide to a Complex Framework for the Analysis of Institutions and Their Development." Policy Studies Journal 39 (1): 169-82.

Provan, Keith G, Amy Fish, and Joerg Sydow. 2007. "Interorganizational Networks at the Network Level: A Review of the Empirical Literature on Whole Networks." Journal of Management 33 (3): 479-516.

Rittel, Horst, and Melvin Webber. 1973. "Dilemmas in a General Theory of Planning.” Policy Sciences 4 (2): 155-69. 
Sabatier, Paul A., and Hank Jenkins-Smith, eds. 1993. Policy Change and Learning: An Advo- cacy Coalition Approach. Boulder, CO: Westview Press.

United Nations 2015. Transforming Our World: The 2030 Agenda for Sustainable Development. General Assembly, 70(1): 1-2.

Peraturan Daerah Nomor 6 Tahun 2016 Tentang Pembentukan dan Susunan Perangkat Daerah.

Peraturan Bupati Pinrang Nomor 37 Tahun 2016 Tentang Pembentukan Bagian Penanggulangan Kemiskinan.

Nota Kesepahaman (MoU) No. 26 Tahun 2018 Tentang Kerjasama Penanggulangan Kemiskinan

Draf Paparan Focus Group Discussion Tentang Penanggulangan Kemiskinan Bagian Organisasi dan Tata Laksana Sekertariat Daerah Kabupaten Pinrang 2017 